\title{
Implementation of Geographic Information System Base On Google Maps API to Determine Bidikmisi Scholarship Recipient Distribution in Central Sulawesi Indonesia
}

\author{
Nurdin Nurdin ${ }^{1} \square$, Sagaf S. Pettalongi ${ }^{2}$ and Mansur Mangasing ${ }^{3}$ \\ ${ }^{1}$ Faculty of Islamic Economic and Business, Universitas Islam Negeri Palu, Indonesia \\ ${ }^{2}$ Faculty of Islamic Teacher Training and Education Universitas Islam Negeri Palu, Indonesia \\ ${ }^{3}$ Faculty of Islamic Philosophy, Humanities, and Communication, Universitas Islam Negeri Palu, Indonesia \\ $\square$ Corresponding Author: Nurdin Nurdin, E-mail: nnurdin@iainpalu.ac.id
}

\begin{tabular}{ll}
\hline ARTICLE INFORMATION & ABSTRACT
\end{tabular}

Received: 12 October 2021

Accepted: 16 November 2021

Published: 23 December 2021

DOI: 10.32996/jhsss.2021.3.12.5

\section{KEYWORDS}

Geographic information systems, Google Map API, mapping,

Bidikmisi scholarship, university students
The presence of information technology in web-based digital mapping, especially using the Google API, has helped various parties make decisions regarding mapping to find out the distribution of various objects. Bidikmisi scholarship recipients are a group of university students who receive fundings Indonesian government every year. They come from various regions and economic backgrounds. However, the distribution of origin of students receiving the Bidikmisi scholarships has never been investigated accurately. As a result, information related to the geographical distribution of Bidikmisi scholarship recipients, both from an economic point of view and the quality of their education, has not yet been mapped. This study, therefore, developed a geographic information system (GIS) application based on google API to map the distribution of students receiving Bidikmisi scholarship based on region and economic geography. Data were gathered through surveys and interviews with experts and stakeholders from the State Islamic University of Datokarama Palu, Indonesia, to obtain information regarding the GIS design and also the criteria for Bidikmisi scholarship recipients. The results of the study show that 305 students received the scholarship from twelve regencies in Central Sulawesi, Indonesia. The origins of the students were successfully mapped throughout the province. Our study helped universities, especially in the field of student affairs and the Quality Assurance Department, to monitor the distribution of Bidikmisi scholarship recipients. Our study can be used as a reference in making quick and accurate decisions in future scholarship distribution.

\section{Introduction}

Geographic Information System (GIS) can be the most important instrument in supporting the decision-making process related to mapping the distribution of various objects and problems (Claus, 2006; Hess et al., 2004). Therefore, the need for information related to the geospatial (spatial) aspect has become one of the areas of study of the Geographic Information System (GIS). In general, GIS is a computer-based information system used to process georeferenced spatial data (such as facts, conditions, details), which will then be stored in a database (Maliene et al., 2011). A number of studies have been carried out related to various problems that can be solved through the application of GIS, including research related to student mapping (Sanders et al., 2001), college location mapping (Dache-Gerbino, 2017), food stock mapping (Fast \& Rinner, 2018). Mapping of population migration patterns (Chow et al., 2018) and mapping tourist locations (Wan et al., 2018).

The results of research related to the application of GIS can be a very helpful and important source of decision-making for various government agencies. Estes (2014) provide examples of how local governments can make accurate decisions regarding road planning, environmental impact estimation, communicable disease mapping, and other mappings with the application of geographic information systems within their institutions. Bidikmisi is a scholarship program for students who have an excellent

Copyright: (C) 2021 the Author(s). This article is an open access article distributed under the terms and conditions of the Creative Commons Attribution (CC-BY) 4.0 license (https://creativecommons.org/licenses/by/4.0/). Published by Al-Kindi Centre for Research and Development, London, United Kingdom. 
academic record but they cannot afford to enter a university in Indonesia (Aliyyah et al., 2019). The scholarship was initiated by the Ministry of Research, Technology, and Higher Education in 2010. The main requirement for recipients of Bidikmisi scholarships is an excellent achievement in academic but poor economic condition.

However, the distribution of origins of Bidikmisi scholarship recipients has never been investigated accurately. As a result, information related to the geographical distribution of Bidikmisi recipients, both from an economic point of view and the quality of their education, has not yet been mapped. This information is essential to determine which areas have the most or few recipients of Bidikmisi scholarships. Information related to mapping the number of Bidikmisi students based on their area will be able to provide information to the government and universities regarding which areas have the most outstanding students but are economically weak. The problem of outstanding students and the weak economy are the two main criteria for the recipients of the Bidikmisi scholarship.

For this reason, this research developed and implemented a Geographic Information System (GIS) based on the Google Maps API to map the distribution of students receiving Bidikmisi scholarships at a university in Indonesia. With the GIS, the distribution pattern of outstanding students but have a weak economy can be mapped. The information is useful for the government and other related parties in poverty alleviation or the development of education programs. The results of this research will also be useful for universities in understanding the origins of the regions and student schools receiving Bidikmisi so that they can be used in future decision-making.

This research will use the map provided by Google Maps API. Google Maps API is the development of Google Maps (Gibin et al., 2008; Peterson, 2012; Rousseaux \& Lhoste, 2009; Zhu, 2012). The Google Maps API is a set of JavaScript classes that allow users to customize and embed Google Maps in their web pages (Zhu, 2012). So the Google Maps API is a programming function provided by Google maps so that Google maps can be integrated into the Web or applications that are being created by users.

The analysis of the distribution of origin of the Bidikmisi scholarship recipients is important because of the increasing diversity of origins of students with high achievement, but their economic background is weak. Students in Indonesian universities who study at various government universities are increasingly diverse from where they come from and their economic background (Rohsulina et al., 2015).

The availability of accurate data about the different regions of origin of Bidikmisi scholarship recipients becomes to be a driving factor for the successful management of Bidikmisi students in the future. So far, there has been no use of information technology to map the distribution of Bidikmisi scholarship recipients to provide accurate information for decision-making in granting Bidikmisi scholarships every year. Our study was conducted to provide information in evaluating the distribution of Bidikmisi scholarship recipients at universities in Central Sulawesi in Indonesia.

\section{Literature Review}

\subsection{Previous Studies}

A number of previous studies have developed and applied Geographic Information Systems (GIS) for various purposes to assist decision-making. Research related to the movement and distribution of humans using geographic information systems (GIS) is increasingly getting the attention of experts today. Research related to GIS will help various parties in making decisions regarding the trend of the distribution of humans and various other objects (Ma et al., 2018). GIS has become one of the most important data sources in assisting the development and understanding of the distribution of the current human population, and GIS also provides an opportunity for policymakers to access population data based on online maps (Chow et al., 2018; Mulvey \& Curtis, 2018).

GIS research that has been carried out includes the development of a geographic information system (GIS) to determine the location of universities (Almeida et al., 2009), GIS for public health mapping (Richards et al., 1999), GIS for mapping the distribution of floods and food stocks (Bedient et al., 2018), GIS for mapping groundwater and drainage for community empowerment (Das $\&$ Mukhopadhyay, 2020), GIS for mapping population density (Langford \& Unwin, 1994), GIS to map community Tweeters regarding health complaints (Ghosh \& Guha, 2013), and GIS for mapping areas prone to natural disasters (Morrow, 1999).

In the field of education and GIS research to determine the location of universities made by Falahah (2016), there is also research on GIS conducted by Hammond et al. (2018) related to the use of GIS for learning environmental subjects. Then Mitchell, Roy, Fritch, \& Wood (2018) Conducted research related to the use of GIS in collaboration with mathematics and science teachers to facilitate monitoring of volunteering activities in rural areas. However, research related to the use of GIS to determine the distribution of Bidikmisi students has not yet been carried out. Previous research concepts that apply GIS in mapping the welfare of the population can help develop GIS to determine the distribution of students receiving Bidikmisi. 


\subsection{The Concept of Geographic Information Systems}

GIS (Geographical Information System) is a computer-based information system that combines map elements (geographical) and information about the map (attribute data) designed to obtain, process, manipulate, analyze, demonstrate and display spatial data to complete planning, processing, and researching problems. The term "geographic information system" was first used in the 1960 s to refer to a computerized system to help answer questions related to maps that show land use in Canada (Richards et al., 1999). The concept of GIS is then developed in various other fields.

There are two kinds of data processed in GIS, namely geospatial data (spatial data and non-spatial data). Spatial data is data related to geographical conditions such as rivers, administrative areas, buildings, roads, etc. As explained in the image above, spatial data is obtained from maps, aerial photographs, satellite images, statistical data, etc. Until now, in general, human perception regarding the form of representation of spatial entities is the concept of raster and vector. Meanwhile, non-spatial data is in addition to spatial data, namely data in the form of text or numbers, which is usually referred to as attributes. This non-spatial data will explain the spatial data or as a basis for describing the spatial data. From this non-spatial data, spatial data can be formed. For example, if you want to describe a population distribution map, you will need population data from each region (non-spatial data).

Geographic information is data that is placed in the context of space and time. Geographic Information System (GIS) or Geographic Information System (GIS) itself is a computer-based system that is usually used to store, manipulate, and analyze geographic information. Before the existence of this Geographic Information System (GIS), a lot of information on the earth's surface was presented in manually generated maps. The presence of GIS can process the components of the map in a computer. Then the result is a digital map.

GIS can combine various types of data at a certain point on the earth, connect them, analyze them, and map the results. The data processed by this system is spatial data, namely geographically oriented data. In addition, it is also a location that has certain coordinates. This is the basis of reference for the analysis and mapping of the results. Therefore, this GIS application can answer several questions about the earth's geography, such as location, conditions, patterns, modelling, and trends. This capability distinguishes Geographic Information Systems (GIS) from other information systems.

GIS was introduced in Indonesia in 1972 under the name Data Banks for Development. The term Geographic Information System emerged after it was coined by the General Assembly of the International Geographical Union in Ottawa, Canada, in 1967. Initially, this system was an initiative to determine land capability in rural areas of Canada. The trick is to map some information such as land, nature, tourism, agriculture, poultry, at a scale of 1:250.000

\subsection{Google Map API}

API is short for the Application programming interface. In a more straightforward language, APIs are programming functions provided by applications or services so that these services can be integrated with the applications that we make. In comparison, the Google Maps API is a function of programming provided by Google maps that are integrated into the Web. Google Maps API is an interface application that can be accessed via javascript that makes a web page display Google Maps. To be able to access Google Maps on web pages, the Google Maps JavaScript API version 2 requires a Google API Key. API Key is a code that permits be able to display Google Maps on web pages (Leydesdorff \& Persson, 2010).

Spatial analysis, often called spatial analysis, is essentially a location analysis that focuses on three elements of geography: distance, interaction, and movement (Brown et al., 2005). The application of spatial analysis is not only applied to settlement patterns, but to every object or phenomenon, spatial analysis can be applied.

Another expert said that a Geographic Information System (GIS) is a system of tools that can collect, refine, retrieve, transform and visualize spatial data of the earth for certain needs. According to Bernhardsen (Bernhardsen, 2002). In general, a Geographic Information System is a set of manual or computer-based procedures used to store and analyze geographically referenced data.

From this definition, the Geographic Information System can essentially function as:

1. Integrated data bank, which combines spatial and non-spatial data in a Relational Database Management System.

2. Modeling and analysis system, namely as a means of evaluating regional potential and spatial planning.

3. Geographically referenced management system, namely to manage operations and administration that are geographically referenced.

4. Computerized mapping system, which is a system that can present maps as needed. 
The functions mentioned above can work because GIS has the ability to describe geographic data; geographic data that can be described by GIS are:

1. Spatial data relating to positions at certain coordinates.

2. Non-spatial data (attributes) that are not related to the position in the form of colour, name, and so on.

3. The relationship between spatial, non-spatial, and time data.

Geographic Information Systems links spatial data with geographic information about certain features on the map. The feature in question is the appearance of objects on the map in the form of points, lines, or polygons. This information is stored as attributes or characteristics of features that are presented graphically.

\subsection{Geographic Information System Components}

The basic components of a Geographic Information System consist of four kinds (Bernhardsen, 2002):

1. Data entry. Data entry is a procedure for encoding data into a form that can be read by a computer and writing it into the Geographic Information System database. Data entry by converting data from analogue format to digital format. The data entered in the GIS has two types of data: spatial data and attribute data (non-spatial data). Spatial data presents the geographic location of a feature. Points, lines, and areas represent geographic features such as roads, forests, land parcels, and others. Attribute data provides descriptive information such as road names, forest composition, or land parcel names. The data entry methods commonly used in GIS are through the keyboard, digitizing with a digitizer device, scanning, geometric coordinates, converting digital data files.

2. Data management. This component contains functions for storing and recalling data. The input data in the GIS is managed in such a way in a database system. A database is defined as a collection of interconnected data stored together with little redundancy and capable of serving more than one user. Conceptual organization in a database is called a data model. There are three data models used in organizing attribute data, namely: hierarchical, network, and relational data models. In contrast, the spatial data model can be in the form of vector data and raster data.

3. Data manipulation dan analysis. In this manipulation and analysis function, the data is processed in such a way as to obtain the desired information from the geographic information system. Manipulation and analysis by making algorithms from graphic data and attributes in the form of overlaying graphic data as well as linking graphic data and attributes.

4. Output data. Data presentation is a procedure for presenting information from GIS in the form desired by the user. Data output is presented in hardcopy and softcopy. Output in hardcopy format is a permanent display, usually printed on paper, photographic film, or other materials. Output in softcopy is presented through a computer screen in the form of text or graphics or as a step to view the analysis results before being printed permanently.

\section{Methodology}

\subsection{Research Approach}

Research using a mixed-method approach (Jokonya, 2016; Venkatesh et al., 2013). The mixed-method is a data collection and analysis procedure that is carried out by mixing qualitative and quantitative at the same time (Nurdin, 2021) on an object of research such as a case study (Creswell \& Clark, 2011). Qualitative data in this study were collected through focus group discussions (FGD) and interviews with several stakeholders regarding the design and application of GIS applications for mapping the distribution of Bidikmisi recipients at a university in Palu city, Indonesia (Grace et al., 2021). In contrast, quantitative data will be collected through distributing questionnaires to users of the GIS application after being applied to determine the level of distribution of Bidikmisi students regarding the ease of use, benefits, quality, and functionality of the GIS application. 
This research focuses more on software engineering using the prototyping paradigm in making the application, as shown in Figure 1 below:

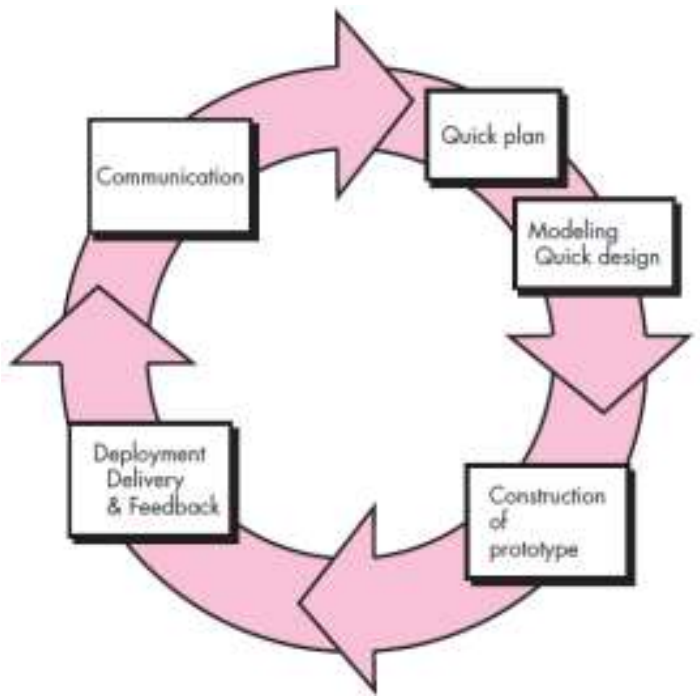

Source: Pressman (2010)

Figure 1: Prototyping Paradigm in Application Development

In the paradigm of making applications with prototyping, a plan is made first after receiving input from users. Then proceed with the initial design and manufacture of a prototype application. After that, an evaluation is carried out by asking for input from users, which can be done through interviews or surveys. The results of interviews or surveys are searched for solutions through analysis which is then continued by developing prototype applications (Niknejad, 2011). After developing the prototype, an in-depth literature review begins to reach the most common problems that the prototype faces in the next step (Ilham et al., 2021). After a literature review, quality issues related to the designed prototype were identified, and other problems stemmed from the webbased GIS.

\subsection{Data Sources}

Data collection begins with conducting a review of various literature. A literature review was conducted mainly related to application development and university scholarship regulation (Nurdin \& Aratusa, 2020; Nurdin \& Yusuf, 2020). In the early stages of developing this Android application, it will help clarify researchers' understanding regarding web-based GIS technology. Meanwhile, primary data collection is carried out in the following ways:

\section{a. Focus Group Discussion (FGD)}

Data collection activities with focus group discussions are common (Morgan, 1996, 1997). In this study, two focus group discussions were held with several stakeholders, such as the quality assurance department, the academic department, and the vice chancellor for academics. Then focus group a discussion was also be held with several application development experts. The purpose of focus group discussions is to gain knowledge (Parent et al., 2000) related to GIS application design and also some evaluation criteria in assessing the Bidikmisi scholarship recipient.

\section{b. Interview}

Interviews are a way of collecting data by conducting in-depth questions and answers with several key informants (Minichiello et al., 1990; Turner, 2010). The Interview in this study is a follow-up to the Interview from the focus group discussion. Interviews were conducted with several key informants to obtain an in-depth view of each relevant informant at the university. The interviews were focused on the requirement of the GIS system for the Bidikmisi scholarship management at the university.

\subsection{Data analysis}

The power analysis derived from interviews and focus group discussions largely follow the process suggested by Strauss and Corbin (1998), where the data analysis process is carried out through four iteration stages, namely, open coding, axial coding, and selective coding. In the first stage, the researcher will group the data into various categories based on the literature review's research questions and theoretical constructs. In the next iteration, axial coding is done by making connections between various 
categories and emerging themes (Corbin \& Strauss, 1990). At this stage, various categories of open coding are then extracted into smaller numbers based on the core themes presented by the informants. In the third iteration stage, selective coding helps the researcher in an in-depth study of the various categories that have been identified in the second level coding stage by "refining their meaning and articulating the relationships among the various categories and themes (Jin \& Robey, 2008) to enable the birth of new theories as well as solutions to problems that arose in the interviews.

\section{Results and Discussion}

4.1 System Specification

Application The geographic information system for mapping Bidikmisi scholarship recipients is a web-based application, but currently, it is still running on localhost. To be able to run the Geographic Information System application for mapping Bidikmisi scholarship recipients, several components are needed, including:

1. A computer/laptop with specifications with an Intel Dual-Core processor or above, a minimum memory of $2 \mathrm{~GB}$ or above, a hard drive of 250GB or above, a mouse, and has been equipped with Windows/Linux operating system.

2. Search applications (browser machines) such as Mozilla Firefox, Google Chrome, Microsoft Internet Explorer, Opera, Safari, and so on.

3. XAMPP as a web server as long as the application is run on localhost

\subsection{System Process Design}

The system process design describes the interaction between the user and the system. The following diagram illustrates the interaction of the system with the user using a use case diagram.

Table 1. Location data use case scenario

\begin{tabular}{|c|c|}
\hline Use case & Enter location data \\
\hline Actor & Admin \\
\hline Brief description & $\begin{array}{l}\text { The use case is used by actors to process location data } \\
\text { input }\end{array}$ \\
\hline Precondition & $\begin{array}{l}\text { Use case: the actor has logged in and successfully entered } \\
\text { the system }\end{array}$ \\
\hline Main flow & $\begin{array}{l}\text { a. The system displays the admin page } \\
\text { b. Actor inputs location data consisting of } \\
\text { attributes: district name, latitude longitude } \\
\text { c. The actor will click the save button when he has } \\
\text { finished inputting the location } \\
\text { d. The system will save location data } \\
\text { e. After being saved by the system, the location that } \\
\text { has been inputted will automatically appear on } \\
\text { the map by displaying a marker }\end{array}$ \\
\hline Alternative flow & $\begin{array}{l}\text { If the actor does not provide input location data, the } \\
\text { marker will not appear on the map }\end{array}$ \\
\hline Postcondition & $\begin{array}{l}\text { If the use case is executed successfully, the data will be } \\
\text { saved }\end{array}$ \\
\hline
\end{tabular}


Table 2. Student data use case scenario

\begin{tabular}{|c|c|}
\hline Use case & Enter student data \\
\hline Actor & Admin \\
\hline Brief description & $\begin{array}{l}\text { The use case is used by actors to process student data } \\
\text { input }\end{array}$ \\
\hline Precondition & $\begin{array}{l}\text { Use case: the actor has logged in and successfully entered } \\
\text { the system }\end{array}$ \\
\hline Main flow & $\begin{array}{l}\text { a. The system displays the admin page } \\
\text { b. The actor inputs student data consisting of } \\
\text { attributes: Nik, recipient's name, place of birth, } \\
\text { address, district/city, province, study program, } \\
\text { cellphone number, year } \\
\text { c. The actor will click the save button when he has } \\
\text { completed student input. } \\
\text { d. The system will save location data } \\
\text { e. After being saved by the system, the student who } \\
\text { has been inputted will automatically add } \\
\text { information on the map and will display the } \\
\text { student's location. }\end{array}$ \\
\hline Alternative flow & $\begin{array}{l}\text { If the actor does not provide input student data, the } \\
\text { information on the number of scholarship recipients will } \\
\text { not increase }\end{array}$ \\
\hline Postcondition & $\begin{array}{l}\text { If the use case is executed successfully, the data will be } \\
\text { saved }\end{array}$ \\
\hline
\end{tabular}

Table 3. Scenario use case looking for student data

\begin{tabular}{|c|c|}
\hline Use case & Search student data \\
\hline Actor & admin \\
\hline Brief description & $\begin{array}{l}\text { The use case is used by the actor to view the data of } \\
\text { scholarship recipients based on the attributes/data sought } \\
\text { in the search column }\end{array}$ \\
\hline Precondition & Use case: actors need to login \\
\hline Main flow & $\begin{array}{l}\text { a. The system displays the geographic information } \\
\text { system page for scholarship recipients } \\
\text { b. Actors can search for student information based } \\
\text { on the attributes typed in the search field }\end{array}$ \\
\hline Alternative flow & $\begin{array}{l}\text { If the actor doesn't type data in the search field, student } \\
\text { information is only based on data from the selected } \\
\text { district }\end{array}$ \\
\hline Postcondition & - \\
\hline
\end{tabular}


Table 4. Student data use case scenario

\begin{tabular}{|c|c|}
\hline Use case & student data \\
\hline Actor & user \\
\hline Brief description & The use case is used by actors to view student data \\
\hline Precondition & Use case: actors don't need to log in \\
\hline Main flow & $\begin{array}{l}\text { a. The system displays the geographic information } \\
\text { system page for scholarship recipients } \\
\text { b. Actors can see the distribution of the districts } \\
\text { from which the scholarship recipients come from } \\
\text { c. Actors can see the table of existing scholarship } \\
\text { recipients and arrange it as desired } \\
\text { d. Actors can view recipient student data by } \\
\text { pressing the detail button so that they can see } \\
\text { the place and details of the student. }\end{array}$ \\
\hline Alternative flow & 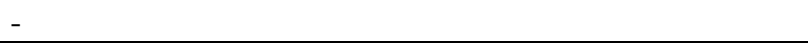 \\
\hline Postcondition & - \\
\hline
\end{tabular}

Table 5. Graphical use case scenario

\begin{tabular}{|c|c|}
\hline Use case & students graph \\
\hline Actor & user \\
\hline Brief description & $\begin{array}{l}\text { The use case is used by the actor to view the graph of } \\
\text { scholarship recipients }\end{array}$ \\
\hline Precondition & Use case: actors don't need to log in \\
\hline Main flow & $\begin{array}{l}\text { a. The system displays the geographic information } \\
\text { system page for scholarship recipients } \\
\text { b. An actor can see the number of students } \\
\text { receiving Bidikmisi each year by clicking on the } \\
\text { graph page }\end{array}$ \\
\hline Alternative flow & e \\
\hline Postcondition & - \\
\hline
\end{tabular}

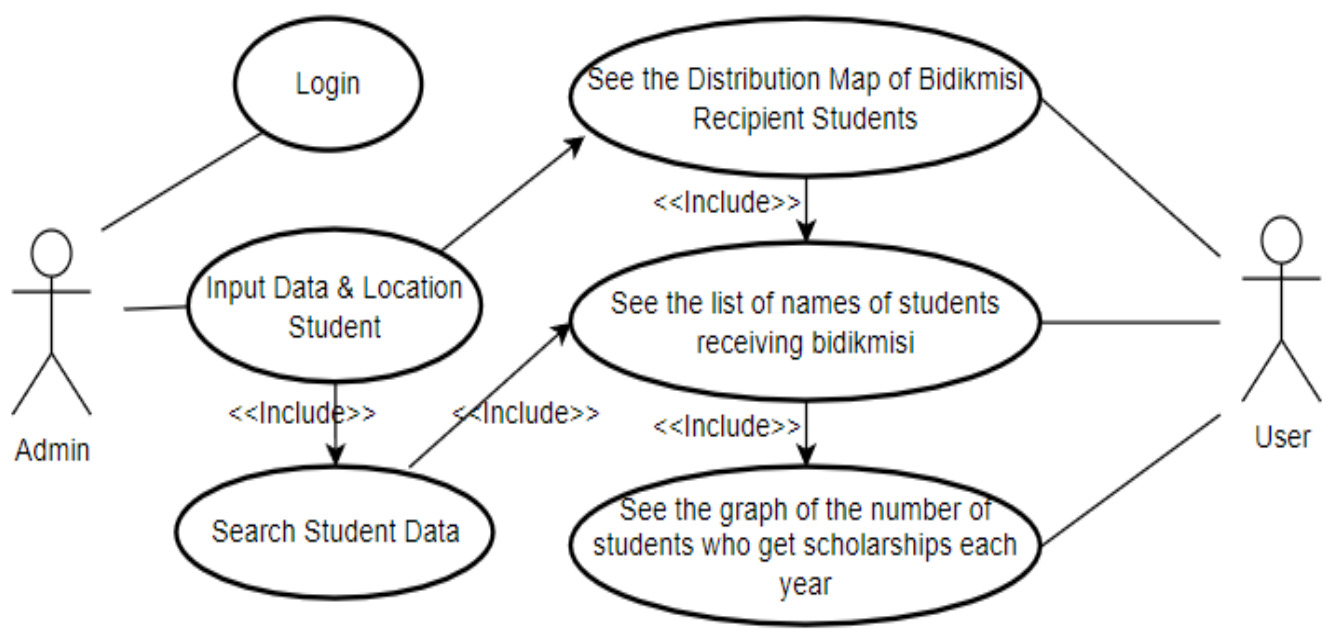

Figure 1. GIS Diagram of Bidikmisi Scholarship Recipients 


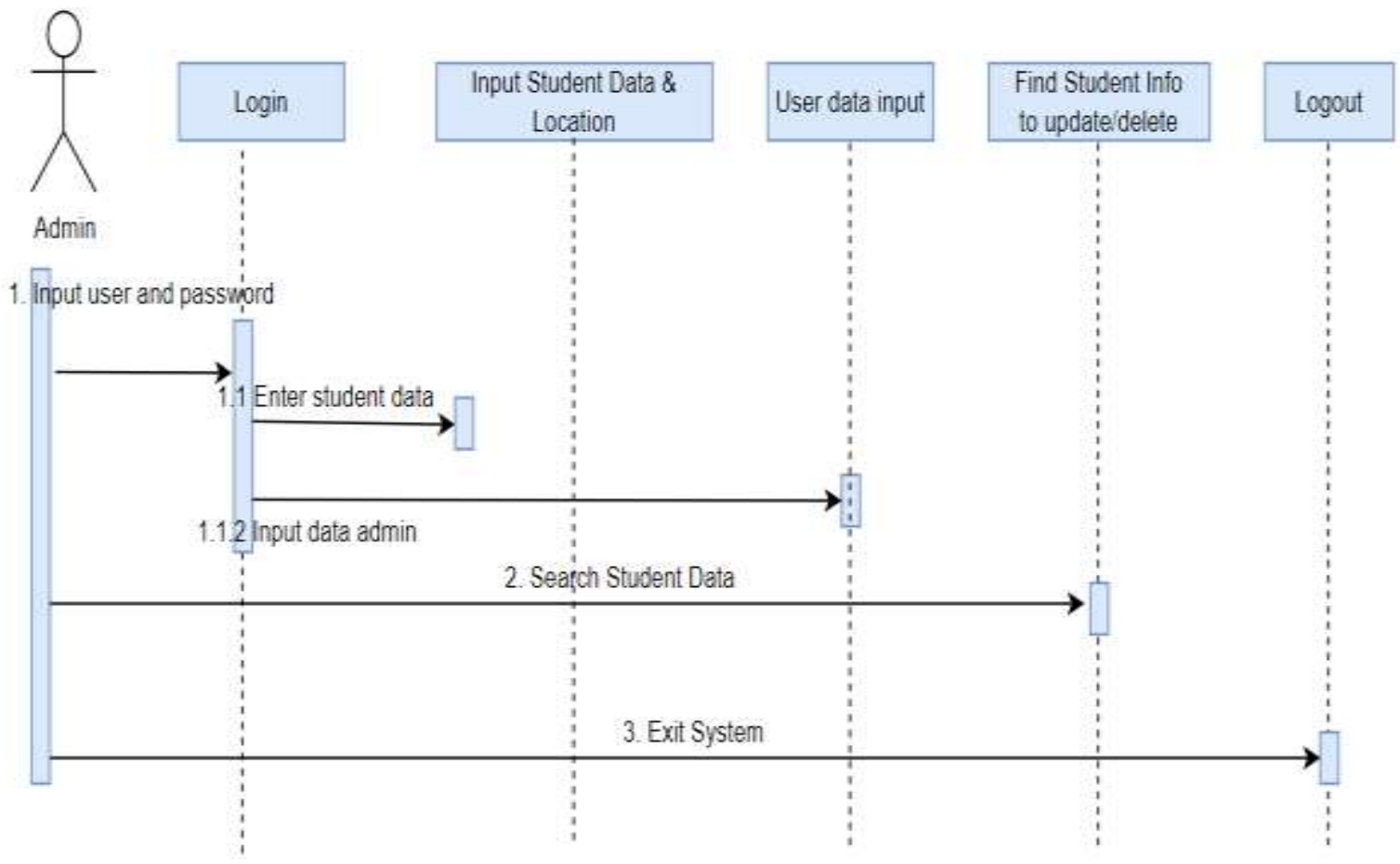

Figure 2. Sequence diagram for admin

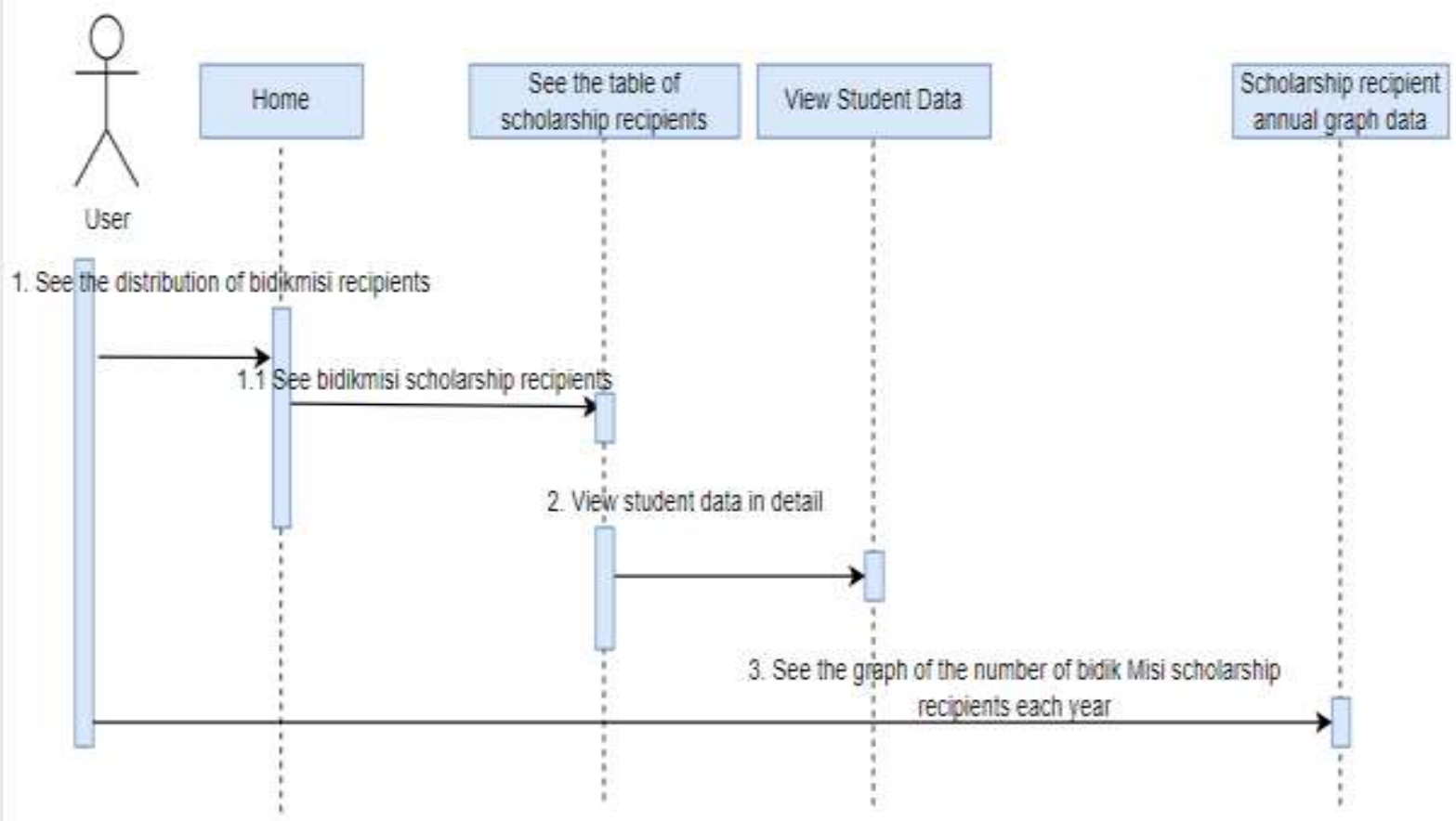

Figure 3. Sequence diagram for user 


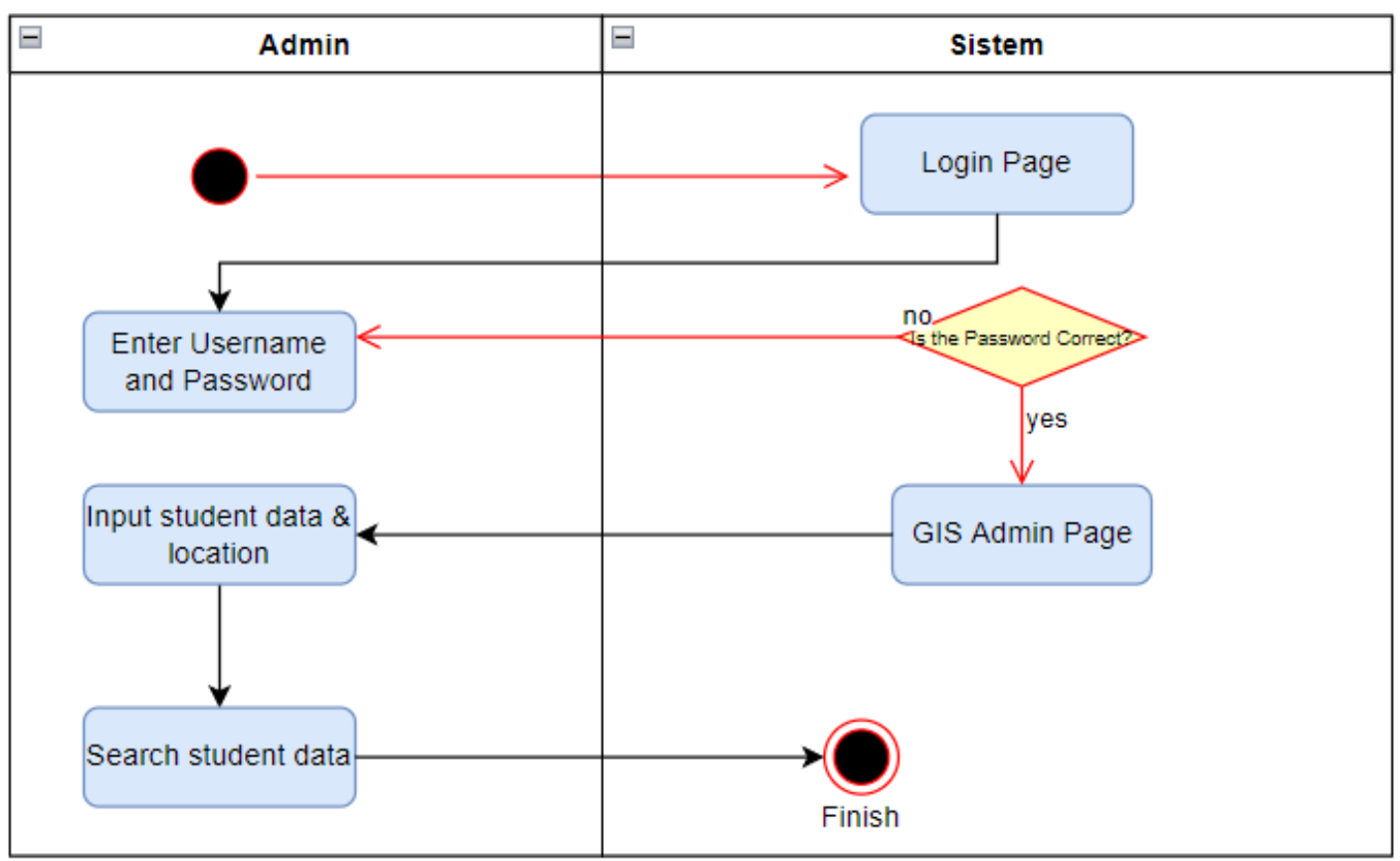

Figure 4. Activity diagram admin

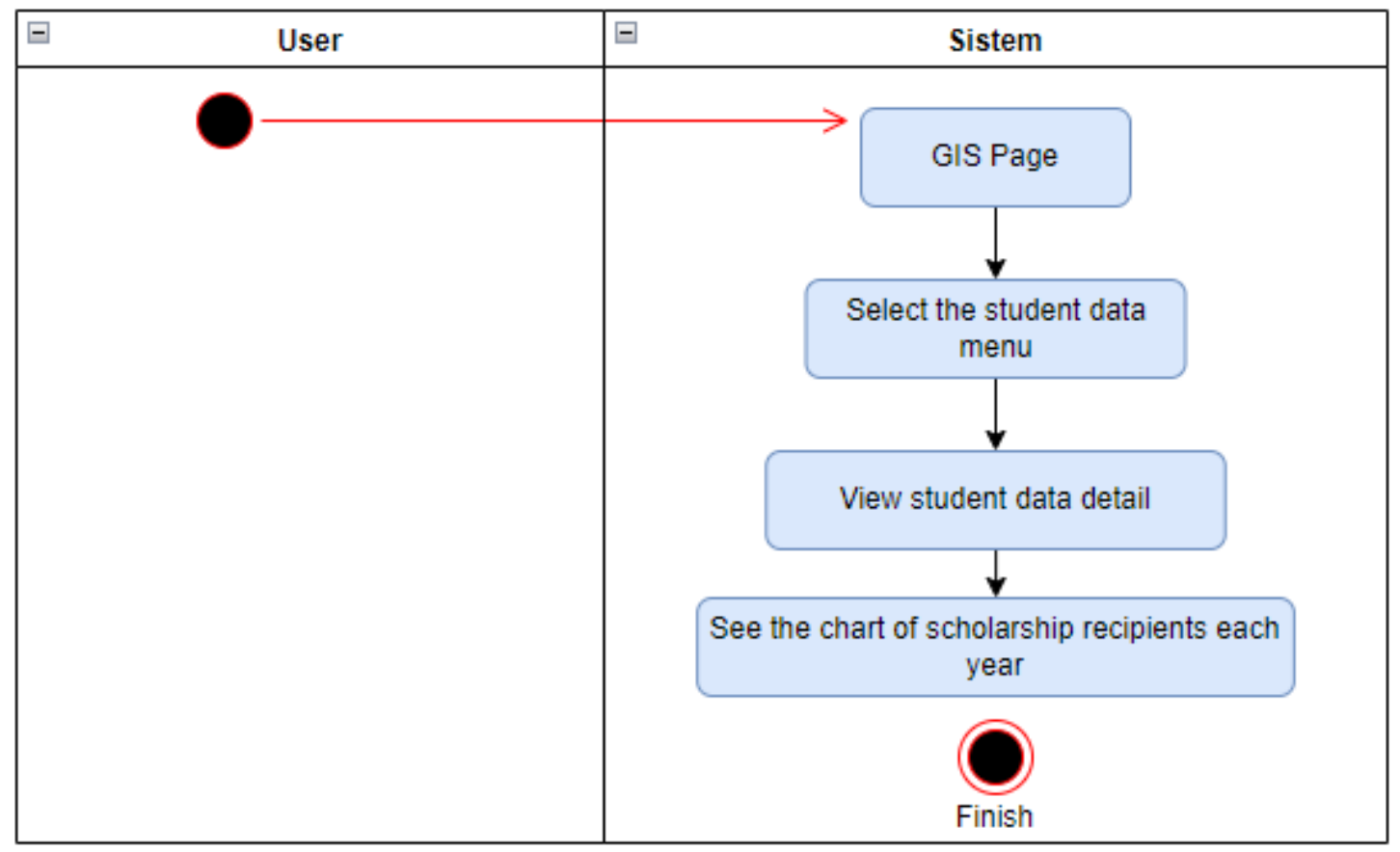

Figure 5. Activity diagram of the user

\subsection{Implementation of the Geographic Information System for mapping Bidikmisi scholarship recipients}

The geographic information system application for mapping Bidikmisi scholarship recipients was installed and activated in XAMPP, then databased also copied into XAMPP by opening a web browser http://localhost/phpmyadmin. When the database has been copied, then the GIS is run. There were three menu pages in the GIS application for mapping the Bidikmisi scholarship recipients, namely Home, Student Data, and Graph of the Bidikmisi Recipients. The homepage displays all Bidikmisi scholarship recipients in the form of markers. The markers are scattered at every location around the address of the student receiving the Bidikmisi scholarship. The Bidikmisi scholarship recipients can be seen by pressing the existing marker so that information about the students 
appears, as shown in figure 6 . The GIS system displayed basic information about the student and notified the user regarding the student's place of origin and also some information about the student.

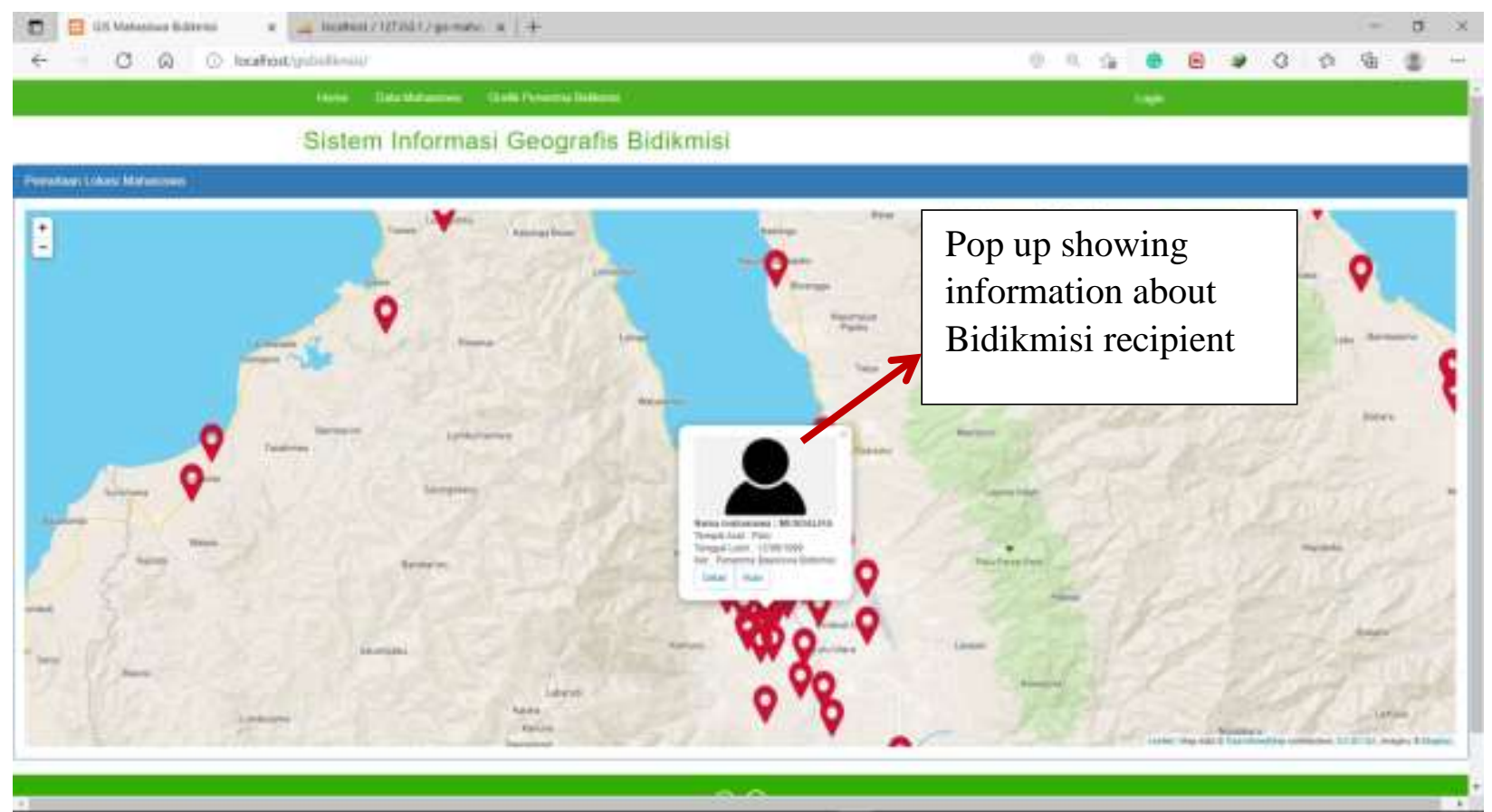

Figure 6. GIS Mapping page for Bidikmisi recipient students by displaying their place of origin

The places where students who received the scholarship can also be seen from satellite as depicted in Google mad. Similarly, the route to monitor the houses and conditions is also shown on the map. The university staff usually monitors the students' house, and economic condition before the scholarship is granted. The monitor was intended to make sure the students were eligible to receive the scholarship as determined by the regulation. As such, the route and students' information can be found in the GIS application. Figure 7 shows the roots of each Bidikmisi scholarship recipient.

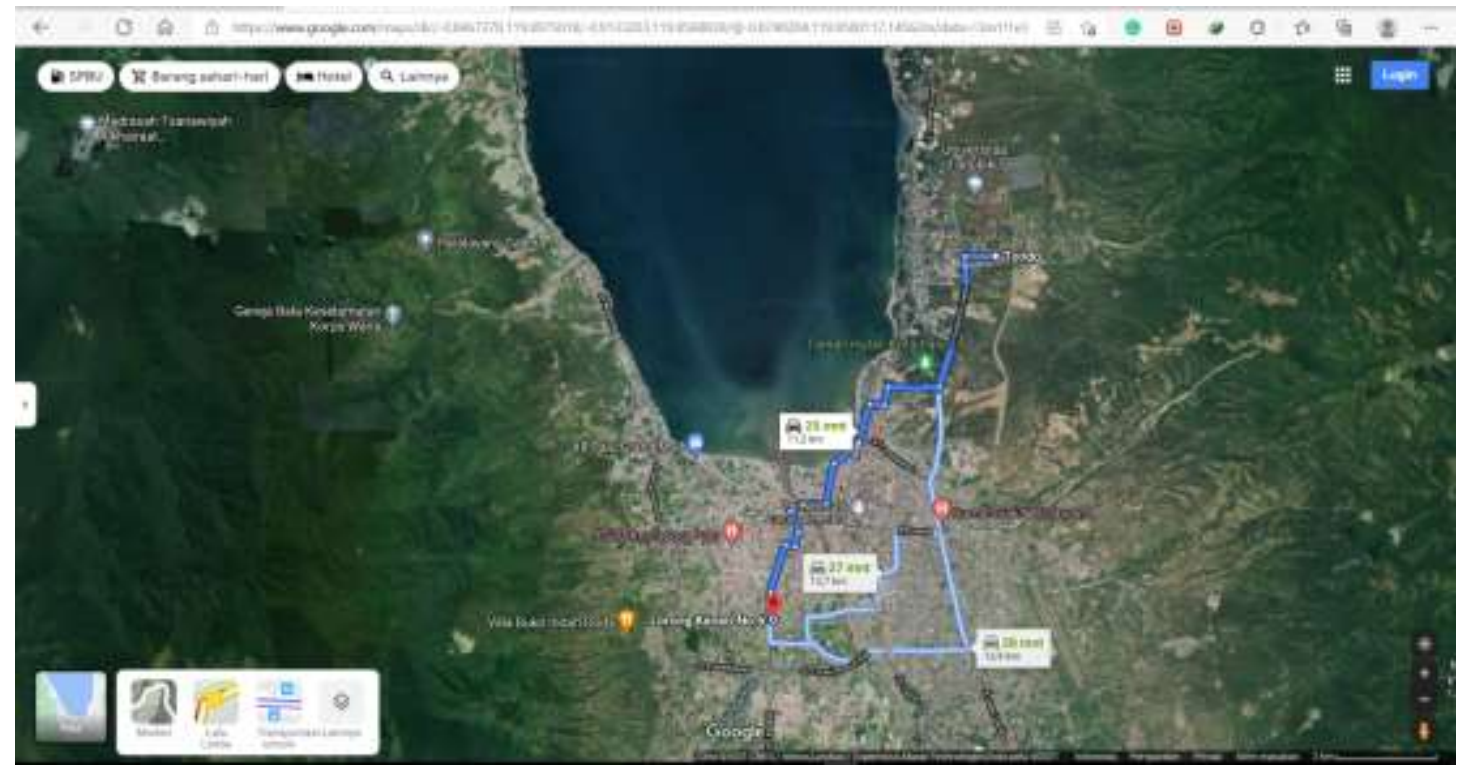

Figure 7. The GIS page for Mapping Bidikmisi recipient and the route to the location of the Bidikmisi recipients

The GIS Mapping page for Bidikmisi scholarship recipients displayed a table of students who received Bidikmisi scholarships. The table consisted of students' names, addresses, place, date of birth, regencies, provinces, study program, year, and other information 
on the recipient of the Bidikmisi scholarship. Meanwhile, the options menu is where information about the details of the place, student photos, and other information appeared when pressing the detail button, as depicted in figure 8 below.

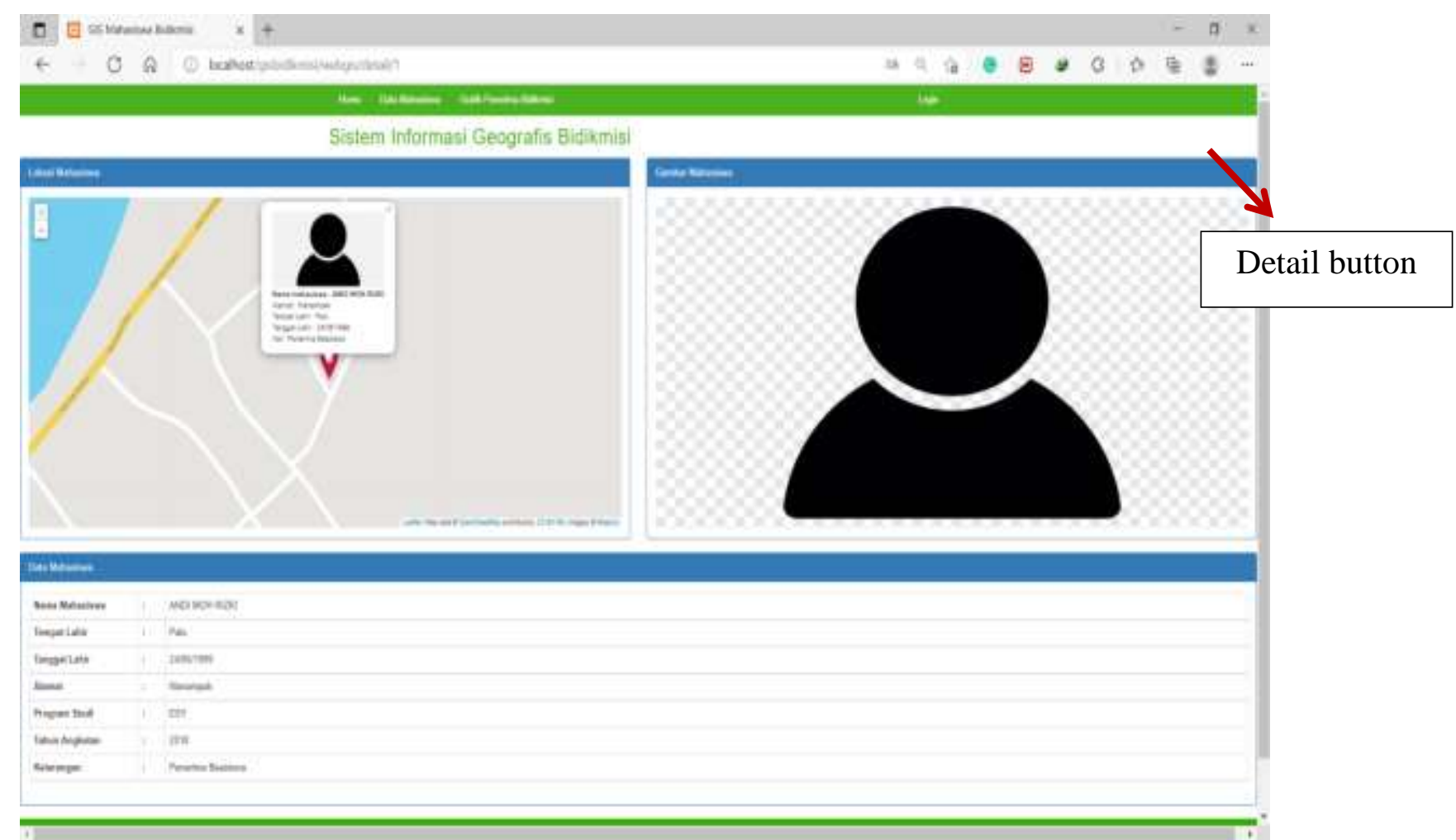

Figure 8. Information page for scholarship recipients

Because this study mapped the Bidikmisi scholarship for the years 2018, 2019, and 2020, the graphs of the students were presented for three years, as shown in figures 9, 10, and 11 below. Each graph showed the Bidikmisi scholarship recipients from each regency in Central Sulawesi province, Indonesia.

\section{Data Penerima Bidik Misi Tahun 2018}

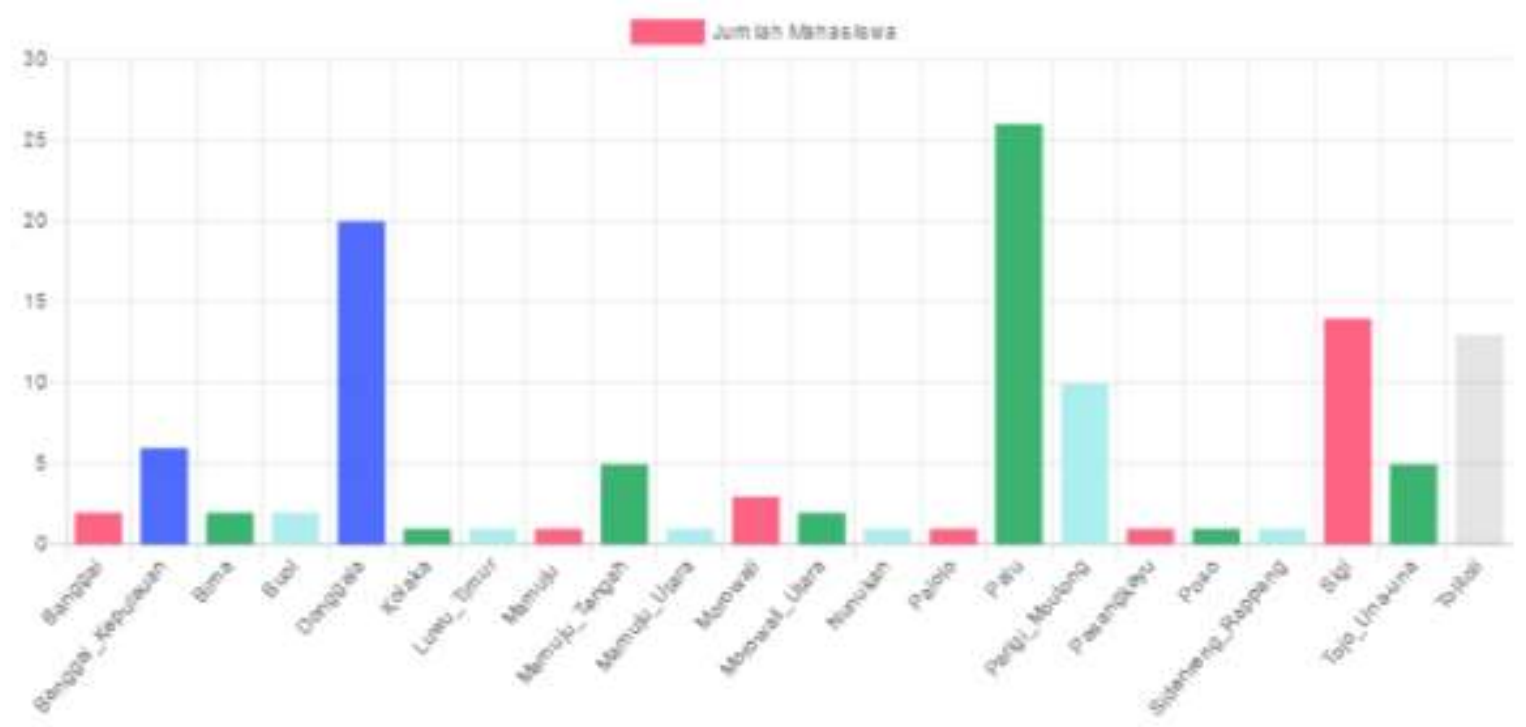

Figure 9. Bidikmisi Scholarship distribution in 2018 


\section{Data Penerima Bidik Misi Tahun 2019}

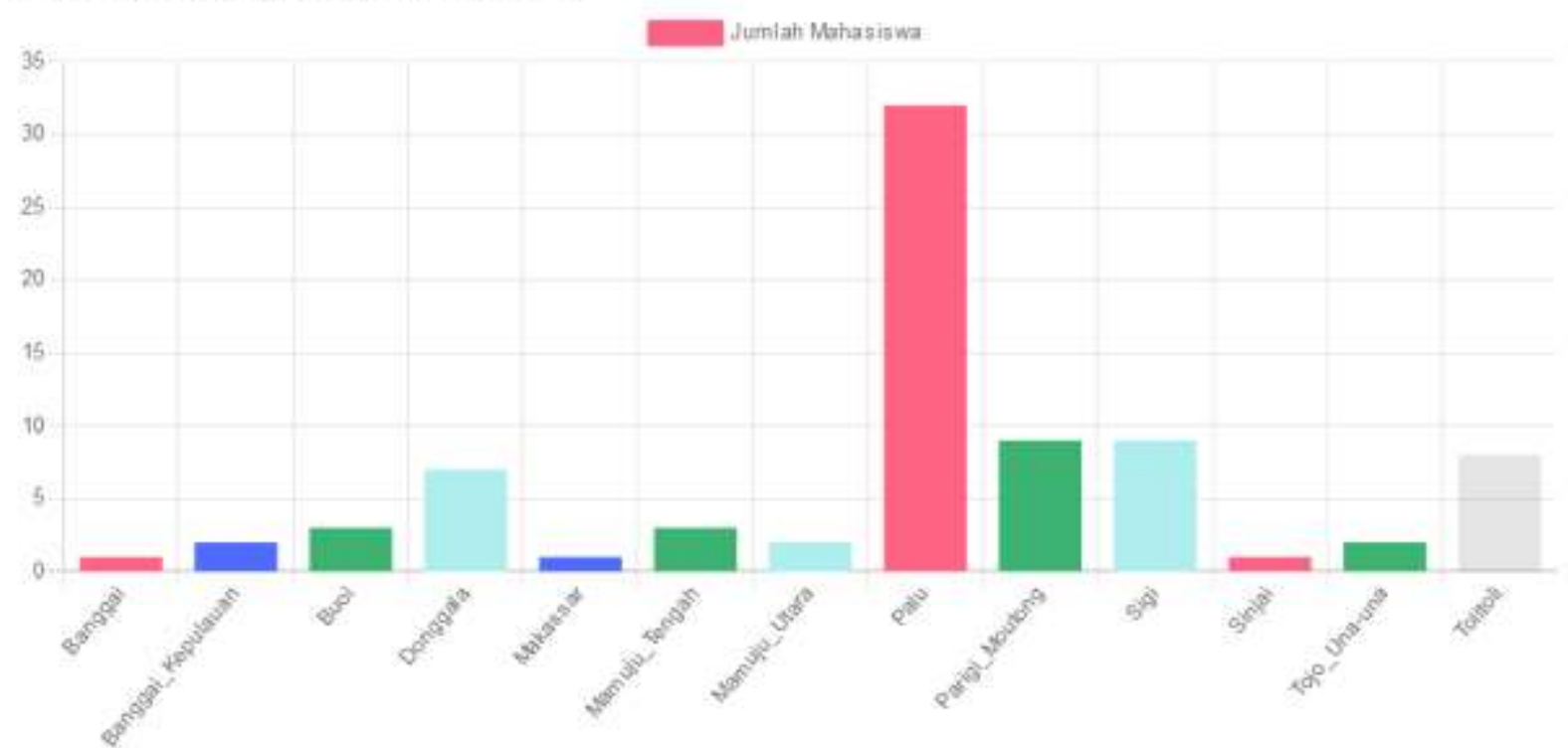

Figure 10. Bidikmisi Scholarship distribution in 2019

\section{Data Penerima Bidik Misi Tahun 2020}

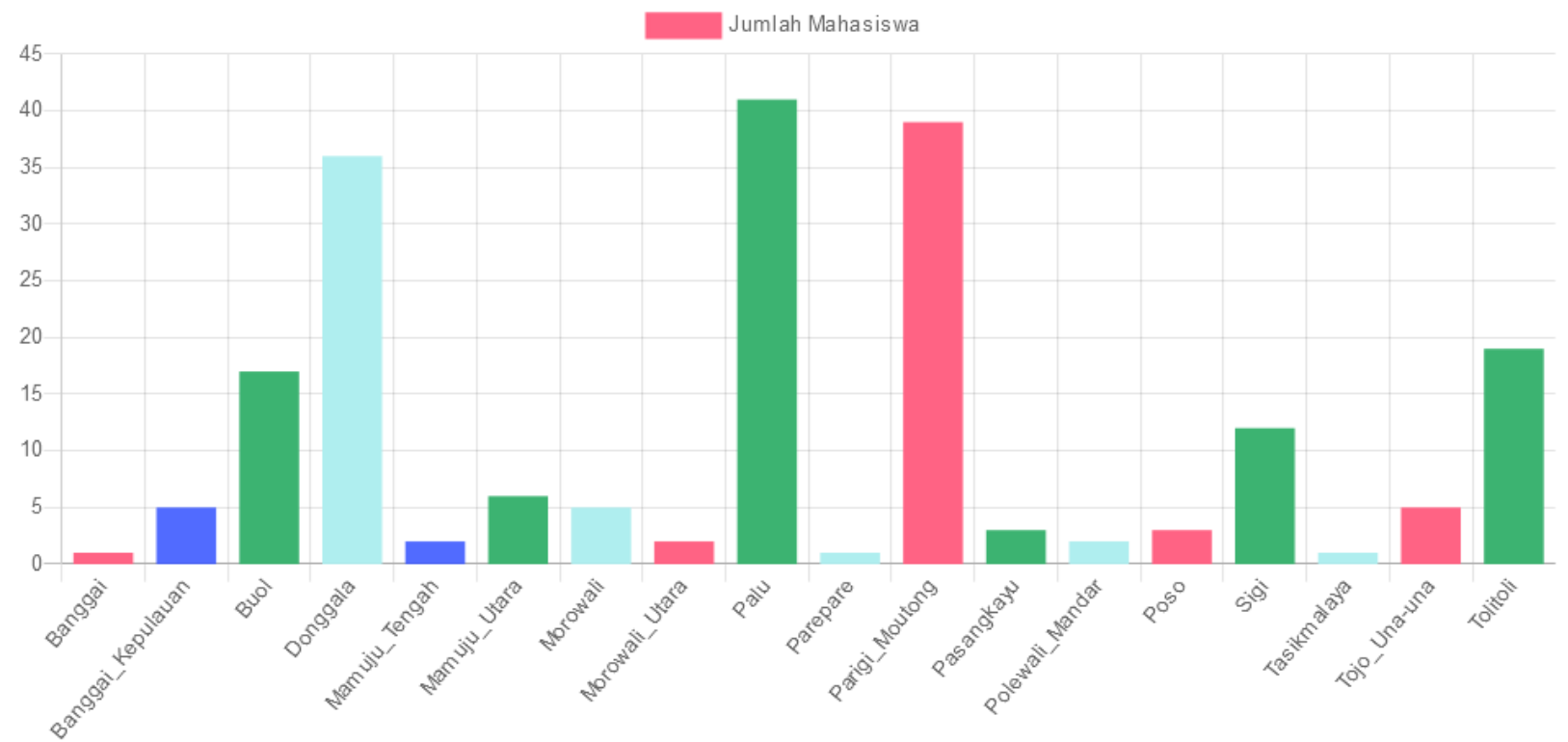

Figure 11. Bidikmisi Scholarship distribution in 2020

On the Student data page, the administrator of the university can also search specific students' names and see more Bidikmisi scholarship recipients by pressing the dropdown records per page. After the student data page, there is also a menu for the user page. The user was an admin who had access rights to enter the students' data page. The admin can add more Bidikmisi recipients' data anytime they need it. The process can make scholarship data management is easier and efficient because all students' data and their geographic distribution can be integrated into the database of the university. The system also allows the academic division to cooperate and coordinate with other divisions in a university (Nurdin, 2018; Nurdin et al., 2014).

This study indicates that 305 students who received the Bidikmisi scholarship for three years have been successfully mapped using a geographic information system. Scholarship recipients are spread across 12 districts in the province of Central Sulawesi. Each student receiving Bidikmisi is indicated by a coordinate on a GIS map containing student data. The university's academic department can use the results of this research to monitor their origins, both their economic conditions and the development of 
their education. Using an information system for scholarship management can support universities to engage successfully with their new potential students (Beugré, 2015; Borges et al., 2017). In addition, regencies can also collaborate in supporting their students' welfare development through the scholarship policy development in Indonesia (Nurdin, 2021).

From the data that has been entered into the GIS, the university was able to map the number of regencies that have received the scholarship based on the economic level and quality of education. From the GIS map, it can also be seen that there are several areas that have a low economy but have good quality education, so students from these areas need to be given the Bidikmisi scholarships.

\section{Conclusion}

We concluded that our study could prove that the students who received Bidikmisi scholarships can be determined their geographic locations using the Geographic Information Systems (GIS) application. The data of the students are easily managed using the GIS systems in which the university can make categorizations based on their regions, and the information can be used for future decision making in the Bidik Misi scholarship distribution based on regions and economic conditions. A region with strong economic performance might not receive more scholarship, while regions with low economic income should be allocated more scholarship as determined by Indonesia's central government regulation. Future research should also focus on mapping the economic performance of each region to provide economic data of university students. The limitation of this study is that some of the scholarship recipients' coordinates were not precisely refected their location. Future research may focus on making precise coordinate points to determine correct students locations.

Funding: This research received funding from State University for Islamic Studies (UIN) Datokarama Palu, Indonesia, grant number 2020, and The APC was also funded by the university.

Acknowledgements: We can acknowledge we received administrative support from the Rector of UIN Datokarama Palu and The Head of LP2M UIN Datokarama Palu.

Conflicts of Interest: The authors declare no conflict of interest

\section{References}

[1] Aliyyah, R. R., Rosyidi, U., \& Yazid, R. (2019). An Evaluative Study of an Education Scholarship Program (BidikMisi) for Students in Indonesia. Journal of Physics: Conference Series, 1175, 1-7.

[2] Almeida, J., Fernandes, H., Filipe, V., \& Barroso, J. (2009, 30 June-2 July 2009). Web Platform Architecture to Support the Geographic Information System of the University of Trás-os-Montes and Alto Douro Campus. 2009 International Conference on New Trends in Information and Service Science,

[3] Bedient, P. B., Huber, W. C., \& Vieux, B. E. (2018). Hydrology and Floodplain Analysis. Pearson.

[4] Beugré, C. D. (2015). The Challenge of Management Scholarship in Africa. Africa Journal of Management, 1(1), 94-98. https://doi.org/10.1080/23322373.2015.994429

[5] Bernhardsen, T. (2002). Geographic Information Systems: An Introduction (3 ed.). John Wiley \& Sons.

[6] Borges, J., Justino, E., Gonçalves, P., Barroso, J., \& Reis, A. (2017, 2017//). Scholarship Management at the University of Trás-os-Montes and Alto Douro: An Update to the Current Ecosystem. Recent Advances in Information Systems and Technologies, Cham.

[7] Brown, D. G., Riolo, R., Robinson, D. T., North, M., \& Rand, W. (2005). Spatial process and data models: Toward an integration of agentbased models and GIS. Journal of Geographical Systems, 7(1), 25-47. https://doi.org/10.1007/s10109-005-0148-5

[8] Chow, T. E., Schuermann, R. T., Ngu, A. H., \& Dahal, K. R. (2018). Spatial mining of migration patterns from web demographics. International Journal of Geographical Information Science, 32(10), 1977-1998. https://doi.org/10.1080/13658816.2018.1470633

[9] Claus, R. (2006). Argumentation Mapping in Collaborative Spatial Decision Making. In B. Shivanand \& D. Suzana (Eds.), Collaborative Geographic Information Systems (pp. 85-102). IGI Global. https://doi.org/10.4018/978-1-59140-845-1.ch005

[10] Corbin, J. M., \& Strauss, A. (1990). Grounded theory research: Procedures, canons, and evaluative criteria [journal article]. Qualitative Sociology, 13(1), 3-21. https://doi.org/10.1007/bf00988593

[11] Creswell, J. W., \& Clark, V. L. P. (2011). Designing and Conducting Mixed Methods Research (2 ed.). SAGE.

[12] Dache-Gerbino, A. (2017). Mapping the Postcolonial Across Urban and Suburban College Access Geographies. Equity \& Excellence in Education, 50(4), 368-386. https://doi.org/10.1080/10665684.2017.1393639

[13] Das, N., \& Mukhopadhyay, S. (2020). Application of multi-criteria decision-making technique for the assessment of potential groundwater zones: a study on Birbhum district, West Bengal, India. Environment, Development and Sustainability, 22(2), 931-955. https://doi.org/10.1007/s10668-018-0227-7

[14] Estes, C. (2014). Geographic Information Systems (Report to the Joint Legislative Oversight Committee on Information Technology, Issue. O. o. I. T. Services.

[15] Fast, V., \& Rinner, C. (2018). Toward a participatory VGI methodology: crowdsourcing information on regional food assets. International Journal of Geographical Information Science, 32(11), 2209-2224. https://doi.org/10.1080/13658816.2018.1480784

[16] Ghosh, D., \& Guha, R. (2013). What are we 'tweeting' about obesity? Mapping tweets with topic modelling and Geographic Information System. Cartography and Geographic Information Science, 4O(2), 90-102. https://doi.org/10.1080/15230406.2013.776210

[17] Gibin, M., Singleton, A., Milton, R., Mateos, P., \& Longley, P. (2008). An Exploratory Cartographic Visualisation of London through the Google Maps API [journal article]. Applied Spatial Analysis and Policy, 1(2), 85-97. https://doi.org/10.1007/s12061-008-9005-5 
[18] Grace, D., Mu'amar, T., \& Nurdin, N. (2021). Sistem Informasi Letak Geografis Penentuan Jalur Tercepat Rumah Sakit Di Kota Palu Menggunakan Algoritma Greedy Berbasis Web. Jurnal Elektronik Sistem Informasi dan Komputer, 4(2), 59-76.

[19] Hammond, T. C., Bodzin, A., Anastasio, D., Holland, B., Popejoy, K., Sahagian, D., Rutzmoser, S., Carrigan, J., \& Farina, W. (2018). "You know you can do this, right?": developing geospatial technological pedagogical content knowledge and enhancing teachers' cartographic practices with socio-environmental science investigations. Cartography and Geographic Information Science, 45(4), 305-318. https://doi.org/10.1080/15230406.2017.1419440

[20] Hess, R. L., Rubin, R. S., \& West, L. A. (2004). Geographic information systems as a marketing information system technology. Decision Support Systems, 38(2), 197-212. https://doi.org/https://doi.org/10.1016/S0167-9236(03)00102-7

[21] Ilham, I., Suwijana, I. G., \& Nurdin, N. (2021). Sistem Pendukung Keputusan Penerimaan Beasiswa Pada SMK 2 Sojol Menggunakan Metode AHP. Jurnal Elektronik Sistem Informasi dan Komputer, 4(2), 48-58.

[22] Jin, L., \& Robey, D. (2008). Bridging Social and Technical Interfaces in Organizations: An Interpretative Analysis of Time-Space Distanciation Information and Organization, 18(3), 177-204.

[23] Jokonya, O. (2016). The Significance of Mixed Methods Research in Information Systems Research. MWAIS 2016 Proceedings,

[24] Langford, M., \& Unwin, D. J. (1994). Generating and mapping population density surfaces within a geographical information system. The Cartographic Journal, 31(1), 21-26. https://doi.org/10.1179/000870494787073718

[25] Leydesdorff, L., \& Persson, O. (2010). Mapping the geography of science: Distribution patterns and networks of relations among cities and institutes. Journal of the American Society for Information Science and Technology, 61(8), 1622-1634. https://doi.org/https://doi.org/10.1002/asi.21347

[26] Ma, T., Zhu, R., Wang, J., Zhao, N., Pei, T., Du, Y., Zhou, C., \& Chen, J. (2018). A proportional odds model of human mobility and migration patterns. International Journal of Geographical Information Science, 1-18. https://doi.org/10.1080/13658816.2018.1514608

[27] Maliene, V., Grigonis, V., Palevičius, V., \& Griffiths, S. (2011). Geographic information system: Old principles with new capabilities. URBAN DESIGN International, 16(1), 1-6. https://doi.org/10.1057/udi.2010.25

[28] Minichiello, V., Aroni, R., Timewell, E., \& Alexander, L. (1990). In-Depth Interviewing: Researching People. Longman Cheshire

[29] Mitchell, J. T., Roy, G., Fritch, S., \& Wood, B. (2018). GIS professional development for teachers: lessons learned from high-needs schools. Cartography and Geographic Information Science, 45(4), 292-304. https://doi.org/10.1080/15230406.2017.1421482

[30] Morgan, D. L. (1996). Focus Group. Annual Review of Sociology, 22, 129 - 152.

[31] Morgan, D. L. (1997). Focus Groups as Qualitative Research. SAGE Publication, Inc.

[32] Morrow, B. H. (1999). Identifying and Mapping Community Vulnerability. Disasters, 23(1), 1-18. https://doi.org/doi:10.1111/1467-7717.00102

[33] Mulvey, B., \& Curtis, J. (2018). Introduction to special content section "The power of mapping in primary and secondary science education". Cartography and Geographic Information Science, 45(4), 289-291. https://doi.org/10.1080/15230406.2018.1429167

[34] Niknejad, A. (2011). A Quality Evaluation of an Android Smartphone Application University of Gothenburg]. Gothenburg, Sweden.

[35] Nurdin, N. (2018). Institutional Arrangements in E-Government Implementation and Use: A Case Study From Indonesian Local Government. International Journal of Electronic Government Research (IJEGR), 14(2), 44-63. https://doi.org/10.4018/ijegr.2018040104

[36] Nurdin, N., Stockdale, R., \& Scheepers, H. (2014). Coordination and Cooperation in E-Government: An Indonesian Local E-Government Case The Electronic Journal of Information Systems in Developing Countries, 61(3), 1-21.

[37] Nurdin, N., \& Aratusa, Z. C. (2020). Benchmarking level interactivity of Indonesian government university websites. TELKOMNIKA Telecommunication, Computing, Electronics and Control, 18(2), 853-859.

[38] Nurdin, N., \& Yusuf, K. (2020). Knowledge management lifecycle in Islamic bank: the case of Syariah banks in Indonesia. International Journal of Knowledge Management Studies, 11(1), 59-80. https://doi.org/10.1504/ijkms.2020.105073

[39] Nurdin, N. (2021). A Collective Action In Indonesia Local E-Government Implementation Success. International Journal Of Scientific \& Technology Research, 10(2), 160-166.

[40] Nurdin, N. (2021). Employing Online and Offline Qualitative Interpretive Case Studies in Understanding E-Procurement Effectiveness. International Journal of Quantitative and Qualitative Research Methods, 9(1), 23-41.

[41] Parent, M., Gallupe, R. B., Salisbury, W. D., \& Handelman, J. M. (2000). Knowledge creation in focus groups: can group technologies help? Information \& Management, 38(1), 47-58. https://doi.org/http://dx.doi.org/10.1016/S0378-7206(00)00053-7

[42] Peterson, M. P. (2012). Online Maps with APIs and WebServices. Springer.

[43] Pressman, R. S. (2010). Software Engineering: A Practitioner's Approach (7 ed.). McGraw Hill.

[44] Richards, T. B., Croner, C. M., Rushton, G., Brown, C. K., \& Fowler, L. (1999). Information Technology: Geographic Information Systems and Public Health: Mapping the Future. Public Health Reports, 114(4), 359-373. http://www.ncbi.nlm.nih.gov/pmc/articles/PMC1308497/

[45] Rohsulina, P., Muh.Husyain, \& Rahman, M. K. (2015). Analisis Persebaran Daerah Asal Mahasiswa Universitas Veteran Bangun Nusantaradengan Menggunakan Sistem Informasi Geografis (SIG). Geoedukasi, 4(2), 9.

[46] Rousseaux, F., \& Lhoste, K. (2009, 1-7 Feb. 2009). Rapid Software Prototyping Using Ajax and Google Map API. 2009 Second International Conferences on Advances in Computer-Human Interactions,

[47] Sanders, R. L., Kajs, L. T., \& Crawford, C. M. (2001). Electronic Mapping in Education. Journal of Research on Technology in Education, 34(2), 121-129. https://doi.org/10.1080/15391523.2001.10782339

[48] Strauss, A., \& Corbin, J. M. (1998). Basics of Qualitative Research: Grounded Theory Procedures and Techniques (2 ed.). Sage Publications, Inc.

[49] Turner, D. W. (2010). Qualitative Interview Design: A Practical Guide for Novice Investigators. The Qualitative Report, 15(3).

[50] Venkatesh, V., Brown, S. A., \& Bala, H. (2013). Bridging the Qualitative-Quantitative Divide: Guidelines for Conducting Mixed Methods Research in Information Systems MIS Quarterly, 37(1), 21-54.

[51] Wan, L., Hong, Y., Huang, Z., Peng, X., \& Li, R. (2018). A hybrid ensemble learning method for tourist route recommendations based on geotagged social networks. International Journal of Geographical Information Science, 32(11), 2225-2246.

https://doi.org/10.1080/13658816.2018.1458988 
[52] Wattal, S., Telang, R., Mukhopadhyay, T., \& Boatwright, P. (2012). What's in a "Name"? Impact of Use of Customer Information in E-Mail Advertisements. Information Systems Research, 23(3-part-1), 679-697. https://doi.org/doi:10.1287/isre.1110.0384

[53] Yang, K., \& Banamah, A. (2014). Quota Sampling as an Alternative to Probability Sampling? An Experimental Study. Sociological research online, 19(1), 29.

[54] Zhu, Y. (2012). Introducing Google Chart Tools and Google Maps API in Data Visualization Courses. IEEE Computer Graphics and Applications, 32(6), 6-9. https://doi.org/10.1109/mcg.2012.114 